\title{
Macroecological and spatial patterns in the distribution of cladocerans in Alpine lakes
}

\author{
Fabio Stoch ${ }^{1,}$, Daria Vagaggini² and Fiorenza Gabriella Margaritora ${ }^{2}$ \\ ${ }^{1}$ Evolutionary Biology \& Ecology, Université Libre de Bruxelles, Avenue F.D. Roosevelt 50, B-1050 Brussels, \\ Belgium. \\ 2 Sapienza University of Rome, Department of Environmental Biology, Viale dell’Università 32, I-00185 Rome, \\ Italy. \\ * Corresponding author: fabio.stoch@ulb.ac.be
}

Received: $15 / 02 / 18 \quad$ Accepted: 10/07/18

\begin{abstract}
Macroecological and spatial patterns in the distribution of cladocerans in Alpine lakes

An extensive data set of the occurrence of 55 cladoceran species in 432 Alpine lakes was used to document patterns of species richness, assemblage composition and distribution across the Alpine ecoregion in Italy, determining the spatial and macroecological parameters explaining the observed patterns. Moreover, the influence of dispersal, environmental filtering and life cycle strategies in shaping cladoceran alpha and beta-diversity patterns was examined. Only three species where widely distributed in the Alpine lakes, with more than $80 \%$ of the species present in less than $10 \%$ of the lakes. Alpha-diversity ranged from 1 to 13 species, while beta-diversity was almost exclusively due to spatial turnover. Our data suggest that the excess of rarity in these environments was better explained by post-glacial random recolonization patterns, high dispersal ability, peculiar life strategies including the production of diapausing eggs, and compliance of cladocerans to the monopolization hypothesis. Spatial determinants (studied using Moran's Eigenvector Maps) were important for large scale species distribution patterns, suggesting that dispersal was not a limiting factor, although altitudinal heterogeneity shaped beta-diversity patterns. The altitudinal gradient (together with the associated macroclimatic factors) was the second main determinant of species distribution, followed by the geological setting of the basins. Local factors played only a minor role in explaining cladoceran distribution patterns at the ecoregional scale.
\end{abstract}

Key words: Lakes, large-scale patterns, beta-diversity, rarity, logarithmic distribution, monopolization hypothesis

\section{RESUMEN}

\section{Patrones espaciales y macroecológicos en la distribución de cladóceros en lagos alpinos}

Una extensa lista de 55 especies de cladóceros de 432 lagos alpinos fue utilizada para estudiar los patrones de riqueza, composición y distribución de especies a lo largo de la ecorregión alpina en Italia, determinando las variables espaciales y macroecológicas que explican los patrones observados. Además, se examinó el efecto de la dispersión, del filtrado ambiental $y$ de las estrategias en el ciclo de vida, en los patrones de diversidad alfa y beta en cladóceros. Solamente tres especies estuvieron ampliamente distribuidas en los lagos Alpinos, con más del $80 \%$ de las especies presentes en menos del $10 \%$ de los lagos. La diversidad alfa, varió entre una y trece especies, mientras que la diversidad beta fue casi exclusivamente debida al recambio en el espacio. Nuestros datos sugieren que la rareza en estos ambientes estuvo mejor explicada por patrones aleatorios de recolonización post-glaciar, alta habilidad de dispersión, estrategias de vida peculiares, incluyendo la producción de huevos diapáusicos y la adaptación de los cladóceros a la hipótesis de monopolización. Las variables espaciales (estudiadas con Moran's Eigenvector Maps) fueron importantes para los patrones de distribución de las especies a gran escala, sugiriendo que la dispersión no fue un factor limitante a pesar de la heterogeneidad altitudinal relacionada con los patrones de diversidad beta. El gradiente altitudinal (junto con los factores macroclimáticos asociados) fue el segundo determinante en la distribución de las especies, seguido por la geología de la cuenca. Los factores locales tuvieron poca 
importancia al explicar los patrones de distribución de los cladóceros a escala ecorregional.

Palabras clave: Lagos, patrones a gran escala, diversidad beta, rareza, distribución logarítmica, hipótesis de monopolización

\section{INTRODUCTION}

Evaluating how different groups of species vary along environmental gradients can provide valuable information on the relative importance of spatial and ecological drivers (Marquet et al., 2004; Pinel-Alloul et al., 2013). Notably, climatic conditions have been often invoked, given that temperature, precipitation and productivity are well correlated with species richness patterns in zooplankton (Hawkins et al., 2003). Moreover, historical hypotheses have also been suggested for formerly glaciated areas, where dispersal processes, influenced by environmental barriers and the presence of local glacial refuges, may have had effects on present-day species richness and distribution patterns (Henriques-Silva et al., 2016). Freshwater microcrustaceans are good candidates to test these hypotheses (Leibold et al., 2010); however, different mating strategies and different life history cycles suggest that Allee effects, i.e. the decrease in the average fitness of individuals in low-density populations, influence the relative importance of environmental filtering and dispersal limitation on species diversity patterns (Courchamp et al., 1999). For this reason, Henriques-Silva et al. (2016) suggested that lumping species with large differences in their susceptibility to Allee effects, like copepods and cladocerans, should be avoided in examining large-scale patterns.

Cladocerans living in Alpine lakes were selected in our study as the target group to document macroecological patterns. Cladocerans were considered good candidates for several reasons: they reproduce almost invariably through cyclic parthenogenesis (De Meester et al., 2002), and, for this reason, should be less subject to the Allee effect than copepods (Henriques-Silva et al., 2016). Moreover, cladocerans are a key group of organisms in many Alpine lakes, comprising an important component of the zooplankton and benthos, and their distribution is well known, especially in the Italian Alps (Tonolli \& Tonolli,
1951; Giussani et al., 1986). The Alpine chain was subject to Quaternary glaciations and re-colonized from local refugia ("nunatakker", e.g. nunatak theory: Dahl, 1987) as well as southern ice-free areas. This well defined ecoregion (Blasi et al., 2014) is highly heterogeneous, shows a strong altitudinal gradient likely to influence species distribution, and a high degree of naturalness. Due to the interaction of historical, ecological and spatial factors, the Alps constitute the ideal scenario to document the role of spatial and ecological determinants shaping cladoceran distribution patterns.

Already in the late $19^{\text {th }}$ and early $20^{\text {th }}$ century, several Alpine lakes were studied and their zooplanktonic fauna described in detail (Zschokke, 1900, 1908; Pesta, 1929). Zschokke (1900) observed no relationship between species richness and altitude, but found that lakes located on granitic substrates generally had more diverse fauna than lakes located in dolomitic areas, suggesting the importance of geological settlement of basins as a further species diversity determinant. More recently, some studies indicated that microcrustacean species composition, including cladoceran assemblages, may be changing in alpine lakes especially due to the introduction of fish (Guilizzoni et al., 2006 and literature cited therein). However, Winder et al. (2001) resampled lakes studied in the early 20th century in Switzerland, concluding that species richness significantly decreased with increasing lake altitude, but no other environmental factor correlated with richness. Consequently, the presence of fish was categorically excluded as a determinant of the absence of large zooplankton (especially Daphnia) in Alpine lakes.

Therefore, although local environmental factors are still claimed as the major determinants of cladoceran species richness and distribution patterns in lakes compared to regional-scale factors (Leibold et al., 2010), the debate is still open (Anas et al., 2014; Pinel-Alloul et al., 2013), and the role of pure spatial factors, as potential 


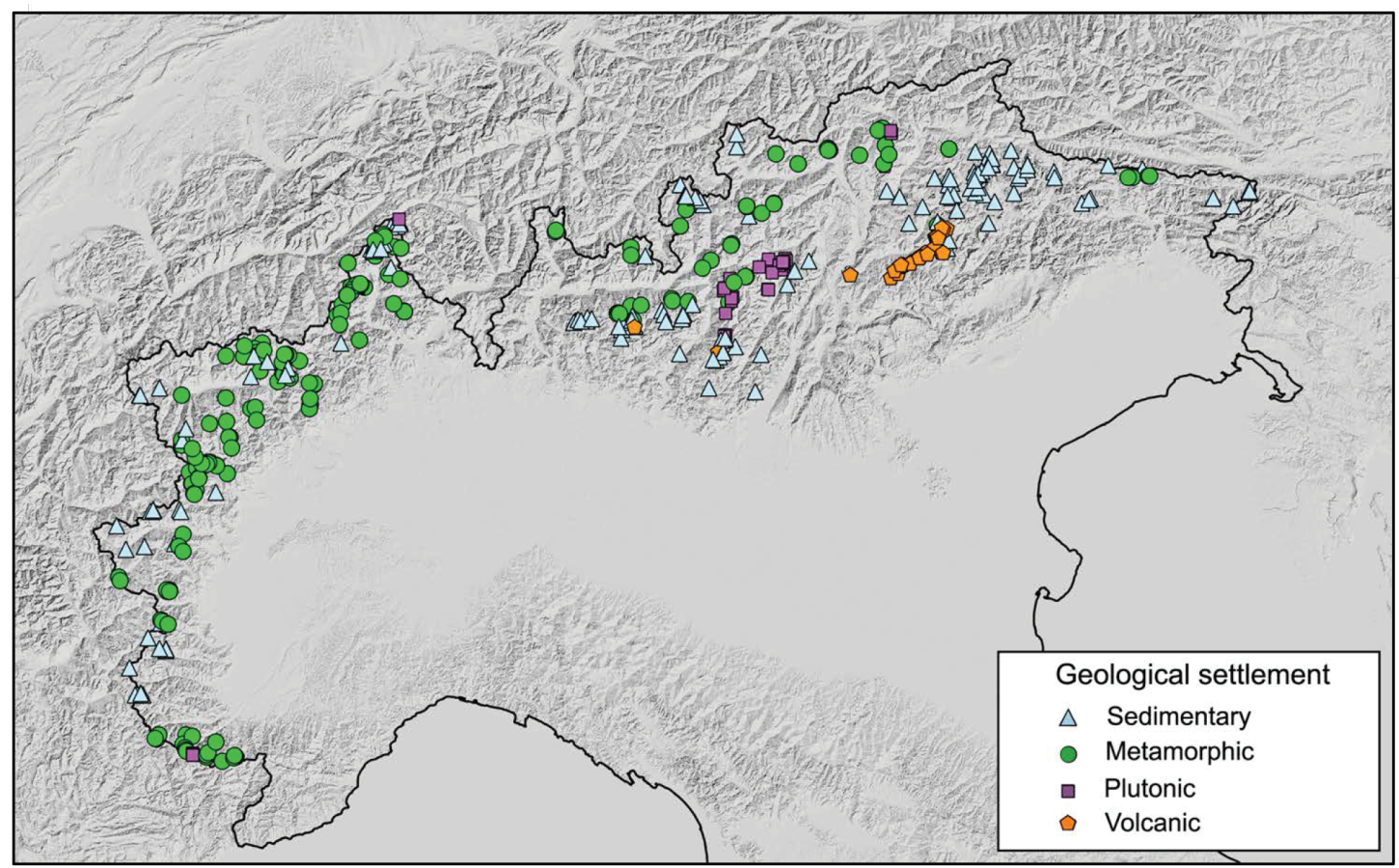

Figure 1. Geographical distribution of the 432 studied lakes and their geological settlement along the Italian Alps. Distribución geográfica de los 432 lagos estudiados y su asentamiento geológico a lo largo de los Alpes italianos.

surrogates of cladoceran dispersal ability, probably underestimated (Sweetman et al., 2010).

The aims of our study, based on an extensive data set of cladoceran distribution in 432 Alpine lakes in Italy, are threefold: (i) document for the first time the patterns of species richness, assemblage composition and distribution of lake cladocerans across the Alpine ecoregion; (ii) determine the spatial and ecological determinants explaining the observed geographical distribution patterns, and (iii) discuss the role of dispersal and environmental filtering in shaping cladoceran diversity patterns at the study ecoregional scale.

\section{MATERIAL AND METHODS}

\section{Study area}

The Alps are the highest and most extensive mountain range system in Europe, stretching about 1200 kilometers across eight countries. The Alpine ecoregion in Italy is a well-defined combination of structural, climatic and biogeo- graphic features (Blasi et al., 2014). In our study the geographical boundaries are those defined by SOIUSA (an Italian acronym for 'International Standardized Mountain Subdivision of the Alps'), the most recent classification system of the Alps (Marazzi, 2005). SOIUSA main classificatory system divides the Alps in 2 main parts (PT: Western and Eastern Alps), 5 sectors (SR), 36 sections (SZ). The sections are useful geographic units for general national reporting and are adopted in our study as main operational units.

\section{Sampling methods and bibliographical review}

The large-scale surveys published by Tonolli \& Tonolli (1951) and Giussani et al. (1986), the monograph of the Italian cladocerans (Margaritora, 1985) as well as the database of cladoceran distribution in Italy produced by Margaritora (2005), updated to 2017 with new literature and collection records, were used as starting points for compiling the species distribution matrix used in the analyses. A database of the native cladocer- 
ans reported to occur in the Alpine ecoregion was compiled from these sources after an extensive and critical literature review (see Supplementary information, available at http://www.limnetica. net/en/limnetica).

An extensive, integrative sampling survey was carried out (1990-2014) on 108 lakes widespread along the whole Alpine arc in Italy. In each lake two samples were collected in July-August. Zooplankton samples were collected in the deepest point of the lakes, when possible with the aid of a small inflatable boat. The plankton net (mouth $25 \mathrm{~cm}$ diameter, $60 \mu \mathrm{m}$ mesh size) was towed vertically from the bottom to the surface. Littoral samples were taken using the same net or a hand-net (semicircular mouth $25 \mathrm{~cm}$ diameter, same mesh size) along the shoreline. Sample fixation in $4 \%$ formaldehyde or $96^{\circ}$ ethanol (especially useful for large-bodied Daphniidae) was carried out in the field to avoid damage to body shape and the morphological characters used for identification. Lake morphometric parameters (maximum depth and area) were measured in the field, together with selected limnological parameters (water temperature and conductivity); the presence of fish was annotated. Samples were sorted under a stereoscopic microscope (20X $60 \mathrm{X})$ and cladocerans separated from detritus, labelled and stored in $75^{\circ}$ alcohol for conservation in small vials. Identification was carried out under a compound microscope by FGM. Cladoceran identifications were based on Margaritora (2005), with the exception of those taxa which changed rank or were synonymized after the publication of this reference work (Adamowicz \& Purvis, 2005; Van Damme et al., 2010). Samples were deposited in the collection of "La Specola" Museum of the University of Florence.

Considering the uncertain status of cladoceran subspecies (especially in the genera Daphnia and Ceriodaphnia), they were not considered as separate units when compiling the occurrence matrix. As regards the genus Daphnia, molecular methods applied to the Daphnia longispina (O. F. Müller, 1776) species complex, widespread on the Alps, suggested that some well-distinguishable morphospecies (like $D$. hyalina Leydig, 1860, $D$. zschokkei Stingelin, 1894 and D. rosea Sars, 1862) should be considered as ecotypes of $D$. longispina (Petrusek et al., 2008). The widespread establishment of clonal populations (Haileselasie et al., 2016) makes the interpretation of the results of molecular studies quite difficult. Pending a thorough revision of these taxa, a conservative approach, according to the recent monograph of Błedzki \& Rybak (2016), was followed, and the updated nomenclature of Fauna Europaea (https://fauna-eu.org) was adopted herein.

Lakes to be included in the species distribution (presence/absence) matrix were selected based on reliable literature records and newly collected samples; only permanent lakes were selected avoiding the inclusion of temporary lakes which can host a peculiar cladoceran fauna; lakes located at an altitude below $1000 \mathrm{~m}$ a.s.l. were discarded. A total of 432 lakes (Fig. 1) were retained for the analyses (see Supplementary information, available at http://www.limnetica. net/en/limnetica).

\section{Regional and local environmental data}

Coordinates of the barycenters of the 432 lakes were obtained both in the field, checking published literature or newly georeferencing lakes using 1:25 000 topographic maps available at the National Cartographic Portal (http://www. pcn.minambiente.it). All the coordinates taken by GPS or published in the literature where carefully verified using Google Earth (http://earth.google. com); precision of georeferencing was about $1 \mathrm{~m}$. Lake area (SUP) was calculated using the tools available in Google Earth and in the National Cartographic Portal. Three sets of regional variables (spatial, geological, and climatic variables) were obtained for each lake and for each geographical area.

Spatial variables. Considering that longitude and latitude alone were unsatisfactory descriptors of spatial relationships along the Alpine arc (which shows a S-N extension in the western part, and a W-E extension in the central and eastern part) as well as of the irregular distribution pattern of sampled lakes, distance-based Moran's Eigenvector Maps (dbMEMs: Borcard \& Legendre, 2002; Legendre \& Legendre, 2012) were used to describe the spatial structure of the dataset. dbMEMs represent a spectral decomposi- 
tion of the spatial relationships, producing orthogonal eigenvectors which were used to represent spatial relationships among sites. The eigenvectors with higher eigenvalues usually describe broad spatial structures, encompassing the spatial variation in the whole study area, while the last positive eigenvectors (with lower eigenvalues) describe finer spatial structures (Dray et al., 2012). Moreover, spatial factors can be interpreted also as surrogates of dispersal processes (Stoch et al., 2016), allowing to gain a better insight into the importance of dispersal as a determinant of cladoceran distribution patterns. Moran's Eigenvectors Maps were computed using R freeware software 3.3.2 (R Development Core Team, 2016), package 'spacemakeR' (Dray, 2008) from a truncated geodesic distance matrix between lake centroids obtained with $\mathrm{R}$ package 'fields' (Furrer et al., 2011). The longest distance connecting two regions in the minimum spanning tree was used as a threshold to truncate the distance matrix. The dbMEMs extracted by the analysis which showed significant correlation with the species distribution matrix (large scale spatial variables: dbMEMs 1, 2, 3; medium scale: dbMEMs 8, 9, and 38) are reported in the Supplementary information, available at http://www.limnetica.net/en/limnetica. The same analysis applied to the Alpine areas used lake-areas centroids and area itself was used as a further spatial variable.

Geological variables. Geological data were obtained for each lake and (as coverage) for each region from the lithological map of Italy (available at http://www.pcn.minambiente.it) at 1:250 000 scale. Five main geological categories were used: plutonic (PLU), volcanic (VOL), metamorphic (MET), sedimentary (non-dolomitic, SED) and dolomitic (DOL) rocks (Fig. 1); dummy variables $(1 / 0)$ were used to include the geological information in the site environmental matrix (one of the variables, VOL, was thus excluded from the analysis, being uninformative having all the values equal to zero).

Climatic variables. The considered environmental variables, besides region area $(\mathrm{A})$, were those representing key aspects of macroclimate and topography. Climatic and topographic variables were obtained from WorldClim 1.4 layers
(Hijmans et al., 2005). Temperature and precipitation values are 1950-2000 means or ranges, interpolated to a 30"' resolution (Hijmans et al., 2005). The following variables were used: mean annual temperature (Tm); maximum temperature of warmest month (Tmax); minimum temperature of coldest month (Tmin); mean annual precipitation $(\mathrm{Pm})$; precipitation of driest quarter (Pdq); precipitation of wettest quarter (Pwq). Actual evapotranspiration (AET) represent 1920-1980 annual means at 30' resolution. AET provides a synthetic index of water-energy dynamics (O'Brien, 2006), which subsumes ambient energy and water availability, two crucial factors determining lake hydrological cycles and productivity. Data on AET were extracted from the world map released by Trabucco \& Zomer (2010). Direct Normal Irradiation (DNI, $1 \mathrm{~km}$ resolution), i.e. the solar radiation component that directly reaches the surface $\left[\mathrm{kWh} / \mathrm{m}^{2}\right]$ was extracted from the layer of the Global Solar Atlas website (Europe and Central Asia), available at http://globalsolaratlas.info/ downloads/europe-and-central-asia. Altitude (ALT) and altitudinal range (ALTr), two of the main controls of climatic heterogeneity, were calculated based on the $20 \mathrm{~m}$ resolution DEM available from the National Cartographic Portal (http://www.pcn.minambiente.it). Point values or mean and range for each SOIUSA section of environmental variables were calculated using QGIS freeware software version 2.18 (QGIS Development Team, 2018).

Local variables. For a subset of 199 lakes (Giussani et al., 1986), some additional local variables were available for each lake i.e. lake depth, Summer water conductivity (measured in July-August), presence/absence of fish, artificial/natural origin of the basins.

\section{Statistical analysis of species diversity}

Point species richness (i.e. alpha-diversity) was defined as the number of cladoceran species recorded in a single lake. Alpha-diversity statistical distribution was fitted using EasyFit software (www.math-wave.com). Relationships between species richness and the main environmental parameters were assessed by means of general- 
ized additive models (GAM) to account for curvilinear relationships. All statistical analyses were performed with $\mathrm{R}$ software. Considering the results of GAM did not differ from that of ordinary least squares (OLS) using log-transformed species richness data, more user-friendly OLS results were used.

Occurrence of crustacean species across the Alpine ecoregion was illustrated by a rank-frequency diagram. The statistical distribution of the number of lakes where each species was present was fitted using EasyFit software as above.

Regional species richness was defined as the number of species contained in each SOIUSA section. Because sampling effort varied among regions, the first-order jackknife estimator of species richness was calculated (Pinel-Alloul et al., 2013): $\mathrm{Sj}=$ Sobs $+\mathrm{r}(\mathrm{n}-1) / \mathrm{n}$, where Sobs is the number of species observed in $n$ lakes and $r$ is the number of species present in one lake. A weak correlation between $\mathrm{Sj}$ and regional area was detected; however, correcting species richness values for regional area did not improve further analyses.
Relationship between regional species richness and selected environmental parameters was assessed using ordinary least squares (OLS) in R.

Overall beta diversity for the whole Alpine ecoregion was measured using $\beta_{\text {sor }}$ (Sorensen's index of dissimilarity) and its components $\beta_{\text {sim }}$ (differences in composition caused by species turnover) and $\beta_{\text {nes }}$ (differences caused by species losses or gains, i.e. nestedness) as implemented by Baselga (2010). A pairwise dissimilarity matrix based on $\beta_{\text {sim }}$ was computed using command beta.pair in R package 'betapart' (Baselga \& Orme, 2012). Agglomerative hierarchical clustering analysis based on the $\beta_{\text {sim }}$ dissimilarity matrix, using command hclust in $\mathrm{R}$ package 'stats' with average linkage, was used in order to identify groups of regions with similar fauna.

The significance of dividing the Alpine ecoregion into the SOIUSA section based on the $\beta_{\text {sor }}$ similarity matrix was assessed by means of Analysis of Similarities (ANOSIM: Clarke, 1993) using the R package 'vegan' (Oksanen et al., 2017). The same analysis was also used to assess

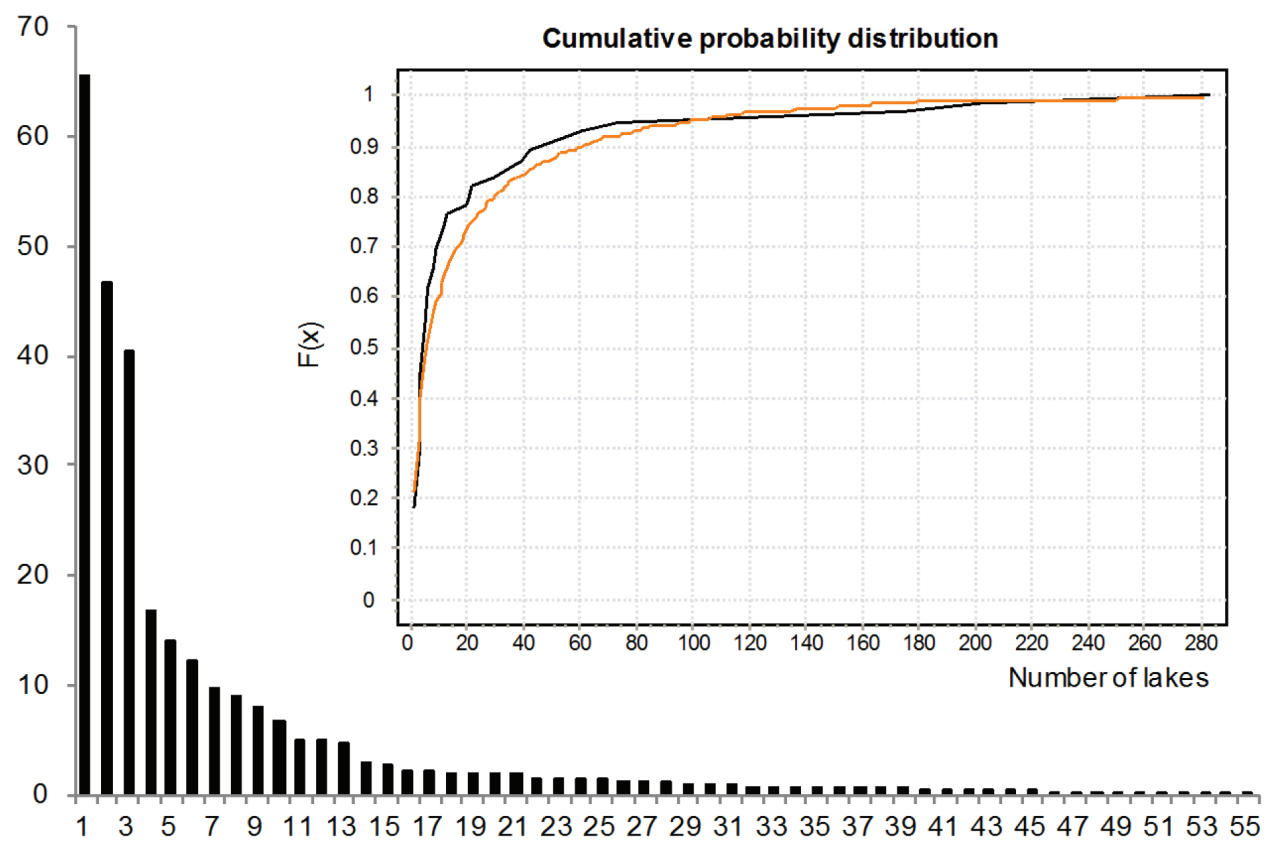

Figure 2. Rank frequency distribution of the 55 cladoceran species found in the studied Alpine lakes. The cumulative probability distribution illustrating the fit with a logarithmic distribution is reported as well. Distribución de la frecuencia de rango de las 55 especies de cladóceros encontradas en los lagos alpinos estudiados. También se presenta la distribución de la probabilidad acumulada y el ajuste con una distribución logarítmica. 
the significance of cutting the $\beta_{\text {sim }}$ - based tree into $\mathrm{n}$ clusters; this use has to be taken with caution, because the underlying argument is circular. For this reason, we merely inspected the results for site groups that were well-distinguished. A non-Metric Multidimensional Scaling analysis was performed in the R package 'vegan' based on the original species distribution matrix to visually inspect the consistence of the classificatory scheme from cluster analysis.

\section{Statistical analysis of species distribution patterns and their determinants}

Spatial and environmental predictors of species distribution patterns were assessed by a distance-based redundancy analysis (dbRDA: Legendre \& Anderson, 1999) using command dbrda in $\mathrm{R}$ vegan package. dbRDA was used because it can be computed with any dissimilarity index and, therefore, $\beta_{\text {sor }}$ could be preserved in the constrained ordination. Collinearity among variables was tested using command vif.cca in R package 'vegan'. After removing highly collinear variables (VIF > 20), a forward selection procedure with double-stopping criteria (Legendre \& Legendre, 2012) was performed to avoid overfitting in $\mathrm{R}$ package 'packfor' (Dray, 2009), allowing to select only those variables that significantly explained the variation in the species dissimilarity matrix.

dbRDA analysis was applied three times to the dissimilarity matrices calculated on the following species distribution data sets: (i) species distribution matrix in lakes (55 species $\mathrm{x}$ 432 lakes); (ii) species distribution matrix of a subset of lakes where local environmental parameters were available (35 species x 199 lakes); (iii) species frequencies in the SOIUSA sections (55 species $\times 13$ sections).

\section{RESULTS}

\section{Cladoceran species richness and assemblage composition}

Among the 55 cladoceran species recorded in the 432 Alpine lakes, the most diversified families were the Chydoridae (21 species) and the Daphniidae (18 species), which together accounted for
$71 \%$ of the total species richness, followed by the Macrothricidae (6 species). The other families included 1-2 species each (Table 1). Three species (Chydorus sphaericus, Daphnia longispina and Alona affinis) were found in more than 40 $\%$ of the lakes, and further three species of Chydoridae (Alonella excisa, Alona quadrangularis, and Acroperus harpae) were found in more than $10 \%$ of the lakes. More than $80 \%$ of the species were present in less than $10 \%$ of the sampled lakes, while ten species were collected from a single lake.

The plot of the rank-frequency occurrences of the 55 cladoceran species (Fig. 2) was highly skewed. The best fit distribution was a logarithmic series (Anderson-Darling test, $p<0.01$ ), with parameter $\theta=0.9905$, which described very well the rarity pattern of Cladocera in Alpine lakes.

The efficiency of sampling effort in assessing Alpine cladoceran species richness was studied using sample-based rarefaction curves and different non-parametric estimators of species richness (Fig. 3). The Chao 2 and ICE estimators converged between 300 and 350 sampled lakes, while the number of uniques (i.e. the number of species found in a single lake) decreased already after approximately 120 sampled lakes, indicating an efficient sampling effort. The species rarefaction curve as well as its estimators continued to increase slowly due to the high number of rare species evidenced by the rank-frequency occurrence. The discrepancy between measured and estimated species richness was around 6 species, i.e. $11 \%$ of the assessed richness using estimators.

The average local species richness (alpha-diversity) per lake in the whole Alpine region ranged from 1 to 13 species (mean \pm standard deviation $=3 \pm 2$, median 2 ). The best fit distribution was a Poisson distribution (Anderson-Darling test, $p<0.01$ ), with parameter $\lambda=2.8495$. The expected decrease in local species richness with altitude was confirmed for cladoceran assemblages; the strength of the relationship between log-transformed lake species richness and lake altitude was assessed using linear regression $(\mathrm{r}=-0.24, p<0.0001, \mathrm{n}=432)$. Similar significant relationships $(p<0.001)$ were detected between local species richness and the climatic factors associated with altitude, like AET ( $\mathrm{r}=$ 
Table 1. List of the 55 cladoceran species reported from Alpine lakes in Italy; acronyms used in figures, number of lakes where present and frequency are reported. Lista de las 55 especies de cladóceros reportadas en los lagos alpinos en Italia. Se indican los acrónimos usados en las figuras, número de lagos en los que hubo presencia y las frecuencias.

\begin{tabular}{|c|c|c|c|c|}
\hline Classification & Species & Acronym & Number of lakes & Frequency \\
\hline \multicolumn{5}{|l|}{ Ctenopoda } \\
\hline \multirow[t]{2}{*}{ Sididae } & Diaphanosoma brachyurum (Liévin, 1848) & Diabra & 8 & 1.9 \\
\hline & Sida crystallina (O.F.Müller, 1776) & Sidcri & 2 & 0.5 \\
\hline Holopediidae & Holopedium gibberum Zaddach,1855 & Holgib & 6 & 1.4 \\
\hline \multicolumn{5}{|l|}{ Anomopoda } \\
\hline \multirow[t]{3}{*}{ Bosminidae } & Bosmina (Bosmina) longirostris (O.F.Müller, 1785) & Boslgr & 35 & 8.1 \\
\hline & Bosmina (Eubosmina) coregoni (Baird,1857) & Boscor & 1 & 0.2 \\
\hline & Bosmina (Eubosmina) longispina (Leydig, 1860) & Boslsp & 10 & 2.3 \\
\hline \multirow[t]{18}{*}{ Daphniidae } & Daphnia (Daphnia) cucullata G.O.Sars, 1862 & Dapcuc & 2 & 0.5 \\
\hline & Daphnia (Daphnia) galeata G.O.Sars, 1864 & Dapgal & 1 & 0.2 \\
\hline & Daphnia (Daphnia) hyalina Leydig, 1860 & Daphya & 12 & 2.8 \\
\hline & Daphnia (Daphnia) longispina O.F.Müller, 1785 & Daplon & 202 & 46.8 \\
\hline & Daphnia (Daphnia) middendorffiana Fischer, 1851 & Dapmid & 8 & 1.9 \\
\hline & Daphnia (Daphnia) obtusa Kurz,1874 & Dapobt & 6 & 1.4 \\
\hline & Daphnia (Daphnia) rosea G.O.Sars, 1862 & Dapros & 13 & 3.0 \\
\hline & Daphnia (Daphnia) zschokkei Stingelin,1894 & Dapzsch & 22 & 5.1 \\
\hline & Ceriodaphnia dubia Richard, 1894 & Cerdub & 2 & 0.5 \\
\hline & Ceriodaphnia laticaudata P.E. Müller, 1867 & Cerlat & 3 & 0.7 \\
\hline & Ceriodaphnia pulchella G.O.Sars, 1862 & Cerpul & 5 & 1.2 \\
\hline & Ceriodaphnia quadrangula (O.F.Müller, 1785) & Cerqua & 21 & 4.9 \\
\hline & Ceriodaphnia reticulata (Jurine,1820) & Cerret & 5 & 1.2 \\
\hline & Ceriodaphnia rotunda G.O.Sars, 1862 & Cerrot & 1 & 0.2 \\
\hline & Ceriodaphnia setosa Matile, 1890 & Cerset & 1 & 0.2 \\
\hline & Scapholeberis mucronata (O.F.Müller, 1785) & Scamuc & 10 & 2.3 \\
\hline & Simocephalus exspinosus (Koch,1841) & Simexs & 2 & 0.5 \\
\hline & Simocephalus vetulus (O.F. Müller, 1776) & Simvet & 39 & 9.0 \\
\hline Moinidae & Moina brachiata (Jurine, 1820) & Moibra & 3 & 0.7 \\
\hline llyocryptidae & Ilyocryptus sordidus (Liévin, 1848) & Ilysor & 1 & 0.2 \\
\hline \multirow[t]{5}{*}{ Macrothricidae } & Drepanothrix dentata (Eurén, 1861) & Drepden & 3 & 0.7 \\
\hline & Lathonura rectirostris (O.F.Müller, 1785) & Latrec & 1 & 0.2 \\
\hline & Macrothrix hirsuticornis Norman \& Brady, 1867 & Machir & 42 & 9.7 \\
\hline & Macrothrix laticornis (Jurine,1820) & Maclat & 4 & 0.9 \\
\hline & Streblocerus serricaudatus (Fischer,1849) & Strser & 9 & 2.1 \\
\hline Eurycercidae & Eurycercus lamellatus (O.F.Müller, 1785) & Eurlam & 6 & 1.4 \\
\hline \multirow[t]{21}{*}{ Chydoridae } & Chydorus gibbus Sars, 1890 & Chygib & 2 & 0.5 \\
\hline & Chydorus ovalis Kurz,1874 & Chyova & 6 & 1.4 \\
\hline & Chydorus sphaericus O.F.Müller, 1785 & Chysph & 283 & 65.5 \\
\hline & Coronatella rectangula (G.O.Sars 1892) & Correc & 29 & 6.7 \\
\hline & Acroperus angustatus G.O.Sars, 1864 & Acroang & 3 & 0.7 \\
\hline & Acroperus harpae (Baird,1835) & Acrohar & 53 & 12.3 \\
\hline & Alona affinis (Leydig, 1860) & Aloaff & 175 & 40.5 \\
\hline & Alona costata G.O.Sars, 1862 & Alocos & 3 & 0.7 \\
\hline & Alona elegans Kurz 1875 & Aloele & 4 & 0.9 \\
\hline & Alona guttata G.O.Sars, 1862 & Alogut & 20 & 4.6 \\
\hline & Alona quadrangularis (O.F.Müller, 1785) & Aloqua & 61 & 14.1 \\
\hline & Alonella excisa G.O.Sars, 1862 & Aloexc & 73 & 16.9 \\
\hline & Alonella exigua Kurz, 1874 & Aloexi & 3 & 0.7 \\
\hline & Alonella nana (Baird, 1843) & Alonan & 9 & 2.1 \\
\hline & Camptocercus rectirostris Schoedler, 1862 & Camrec & 1 & 0.2 \\
\hline & Flavalona costata (G.O.Sars, 1862) & Flacos & 3 & 0.7 \\
\hline & Graptoleberis testudinaria (Fischer, 1848) & Grates & 5 & 1.2 \\
\hline & Pleuroxus aduncus (Jurine, 1820) & Pleadu & 4 & 0.9 \\
\hline & Pleuroxus laevis G.O.Sars,1862 & Plelae & 2 & 0.5 \\
\hline & Pleuroxus striatus Schoedler,1863 & Plestr & 1 & 0.2 \\
\hline & Pleuroxus truncatus (O.F.Müller, 1785) & Pletru & 3 & 0.7 \\
\hline \multicolumn{5}{|l|}{ Onychopoda } \\
\hline Polyphemidae & Polyphemus pediculus (Linnaeus, 1761) & Polped & 1 & 0.2 \\
\hline Cercopagididae & Bythotrephes longimanus Leydig, 1860 & Bytlon & 1 & 0.2 \\
\hline \multicolumn{5}{|l|}{ Haplopoda } \\
\hline Leptodoridae & Leptodora kindtii & Lepkin & 3 & 0.7 \\
\hline
\end{tabular}




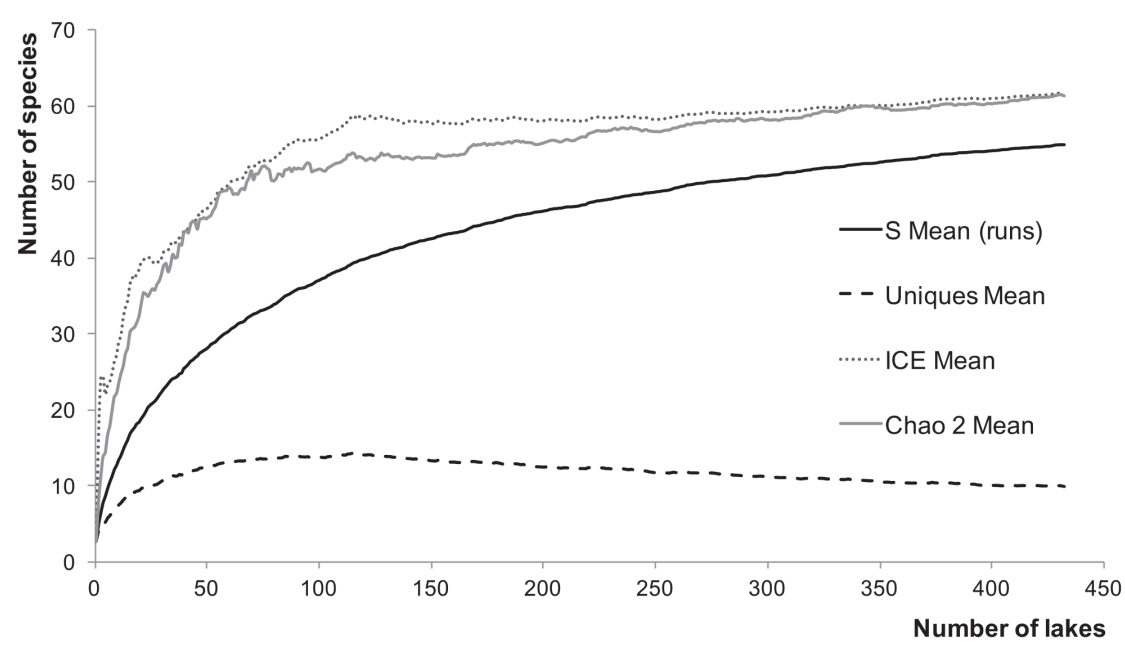

Figure 3. Species rarefaction curves of the cladoceran species richness in the Alpine lakes, variation of non-parametric estimators of species richness (ICE and Chao2) and of the number of uniques with increasing sampling size is illustrated. Curvas de rarefacción de la riqueza de especies de cladóceros en lagos alpinos, variación de estimadores no paramétricos de la riqueza de especies (ICE y Chao2) y del número de valores únicos con incremento del tamaño de muestreo.

0.25), Tmin ( $\mathrm{r}=0.29), \mathrm{Pm}(\mathrm{r}=-0.23)$ and, for a limited lake subset, water conductivity $(r=0.25$, $\mathrm{n}=199$ ). Removing multicollinearity, in a multiple regression elevation (ALT) and solar radiation (DNI) better explained the variation of species richness $(p<0.001)$, together with spatial parameters dbMEMs $1(p<0.01)$ and $2(p<$ $0.001)$. No significant relationships were found between local species richness and lake area, lake depth, and presence of predatory fish.

Overall beta-diversity of cladocerans in the Alpine region $\left(\beta_{\text {sor }}=0.999\right)$ was almost completely caused by spatial turnover $\left(\beta_{\text {sim }}=0.988\right.$, i.e., $99 \%$ ), with only a very small, negligible contribution from nestedness $\left(\beta_{\text {nes }}=0.006\right)$.

The SOIUSA classification system divided the Italian Alps into 15 sections; 13 of them included sampled lakes. The degree to which differences in the composition of cladoceran assemblages (at 432 lakes throughout the Alps in 13 of the SOIUSA sections) matched this a priori regionalization was determined by analysis of similarities (ANOSIM) of Sorensen's similarity measures. ANOSIM analysis indicated that SOIUSA provided a statistically significant classification of cladoceran assemblages in the Alpine lakes (number of permutations: 9999, Global $\mathrm{R}=0.032, p<0.02$ ). However, Global $\mathrm{R}$ was low, thus indicating that, although there was some overall difference in the cladoceran composition of the different regions, only a few of the individual zones could be considered to have compositions that distinguished them from all the other zones.

The total number of cladoceran species found in the Alpine geographical regions (regional gamma-diversity, Jackknife index) ranged from 13 to 44 species $(25.9 \pm 10.6$, median 23). The geographical pattern of regional species richness is reported in Table 2. No longitudinal trend along the Alpine arc was observed; species-rich areas were located in the central (Dolomites and Rhaetian) Alps and Pre-Alps (Brescia and Garda), as well as in the Pennine Alps, whereas some species-poor areas were found in the western (Maritime), northern (Lepontine), and eastern (Carnic) Alps.

The overall beta-diversity pattern for Italian Alps, according to the Bsim -based cluster analysis, reflected two large clusters (Fig. 4a), roughly corresponding to (i) a western and southern Central Alps group and (ii) a northern and north-eastern group, while the central Pre-Alps and the two eastern areas (Carnic and Julian Alps) formed isolated clusters. The clustering classification was highly significant (ANOSIM, number 
Table 2. List of the SOIUSA sections (SZ) of the Italian Alps where the sampled lakes were distributed; section code, area, altitudinal range (ALTr), number of lakes (Nlakes) and cladoceran species richness (SP, Jackknife estimates) are reported. Lista de las secciones SOIUSA (SZ) de los Alpes italianos donde se distribuían los lagos muestreados; código de sección, área, rango altitudinal (ALTr), número de lagos (Nlakes) y riqueza de las especies de cladóceros (SP, estima con Jackknife).

\begin{tabular}{llllll}
\hline CODE Section name & \multicolumn{2}{l}{ Area $\left.\mathbf{( k m}^{2}\right)$} & ALTr & Nlakes & SP \\
\hline SZ.02 & Maritime Alps & 854.90 & 3286 & 26 & 12.9 \\
SZ.04 & Cottian Alps & 3564.50 & 3556 & 37 & 22.8 \\
SZ.07 & Graian Alps & 4077.06 & 4569 & 45 & 18.9 \\
SZ.09 & Pennine Alps & 1619.32 & 4418 & 58 & 36.8 \\
SZ.10 & Lepontine Alps & 1060.10 & 3345 & 29 & 17.9 \\
SZ.15 & Western Rhaetian Alps & 2504.07 & 3800 & 15 & 13.8 \\
SZ.16 & Eastern Rhaetian Alps & 1557.53 & 3496 & 18 & 27.5 \\
SZ.28 & Southern Rhaetian Alps & 4823.41 & 3701 & 49 & 36.8 \\
SZ.29 & Bergamo Alps and Pre-Alps & 3343.42 & 2855 & 47 & 27.9 \\
SZ.30 & Brescia and Garda Pre-Alps & 2647.06 & 2188 & 9 & 40.2 \\
SZ.31 & Dolomites & 6385.67 & 2475 & 83 & 43.9 \\
SZ.33 & Carnic Alps & 4205.35 & 2638 & 9 & 14.3 \\
SZ.34 & Julian Alps & 2996.84 & 2649 & 7 & 23.4 \\
\hline
\end{tabular}

of permutations: 9999, number of permuted statistics greater than or equal to Global R: 0, Global $\mathrm{R}=0.676, p<0.0001)$. However, $\mathrm{a}$ careful examination of the possible pairwise tests showed that only the separation of the two main clusters in Fig. 4b was significant $(p<0.001)$, while the analysis failed in demonstrating the distinctiveness of the isolated clusters from the previous ones. A nMDS analysis (Fig. 4c, 2D stress $=0.14$ ) illustrated better the relationship between the different sections and clusters.

\section{Determinants of species distribution patterns}

The distance-based redundancy analysis (dbRDA) explained only $15.4 \%$ of the variation of the species-distribution matrix. The constrained variation explained by the first two axes of dbRDA was $54.5 \%$, indicating a high, significant correlation between spatial and environmental predictor variables and the species distribution similarity matrix. The environmental and spatial vectors superimposed on the plot as arrows (Fig. $5 b)$ clearly showed that the major determinants of the first axis (explaining $30.2 \%$ of constrained variation) were the spatial eigenvectors (dbMEMs
2-3), representing mainly longitudinal spatial gradients. The second axis $(24.3 \%$ of constrained variation) was an altitudinal gradient, defined by altitude and related morphometric (lake area, larger lakes being located at lower altitudes) and climatic (temperature, precipitation and evapotranspiration) factors, as well as by the medium-scale dbMEM 9, representing mainly a latitudinal spatial gradient. The geological settlement (linked to water chemistry) as well as solar radiation were weakly correlated with the dbRDA axes. The main subdivision of sampled lakes along the first axis was thus determined by the Moran's eigenvectors, which described in detail the spatial structure of the Alpine region. The graph clearly showed that, at a broad spatial scale, lakes were grouped into the two major SOIUSA clusters (Fig. 5a). However, this was not a merely longitudinal gradient, reflecting the results of the cluster analysis. Sections 31 (Dolomites), 10 (Lepontine Alps), 15 and 16 (Rhaetian Alps) (i.e. cluster 5) were projected on the right side of the graph (mainly determined by the spatial vector dbMEM2), while the western sections (2-7: Maritime, Cottian, Graian and Pennine Alps) together with sections 28 (Southern Rhaetian Alps) and 29 (Bergamo Alps and Pre-Alps), i.e. cluster 4, were projected on the left side (mainly defined by dbMEM3). Lakes of section 30 (Brescia and Garda Pre-Alps, cluster 1) were mapped in the lower part of the graph, i.e. were defined by lower elevation and higher temperatures and, to a lesser extent, higher surface area (SUP) and annual evapotranspiration (AET).

Being the amount of unexplained variance in the dbRDA quite high, the analysis was repeated on a subset of 199 lakes for which more parameters (depth, water conductivity, presence/absence of predatory fish, and natural/artificial origin) were available. The dbRDA analysis explained $19.8 \%$ of total variation in the species distribution matrix. The first two axes $(54.3 \%$ of constrained variation, and $10.8 \%$ of unconstrained variation) evidenced the role of depth and naturality in explaining an additional portion of species distribution variation, characterizing the first axis. The second axis reflected a climatic gradient of temperature, precipitation and AET, as in previous dbRDA analysis, while the presence of preda- 

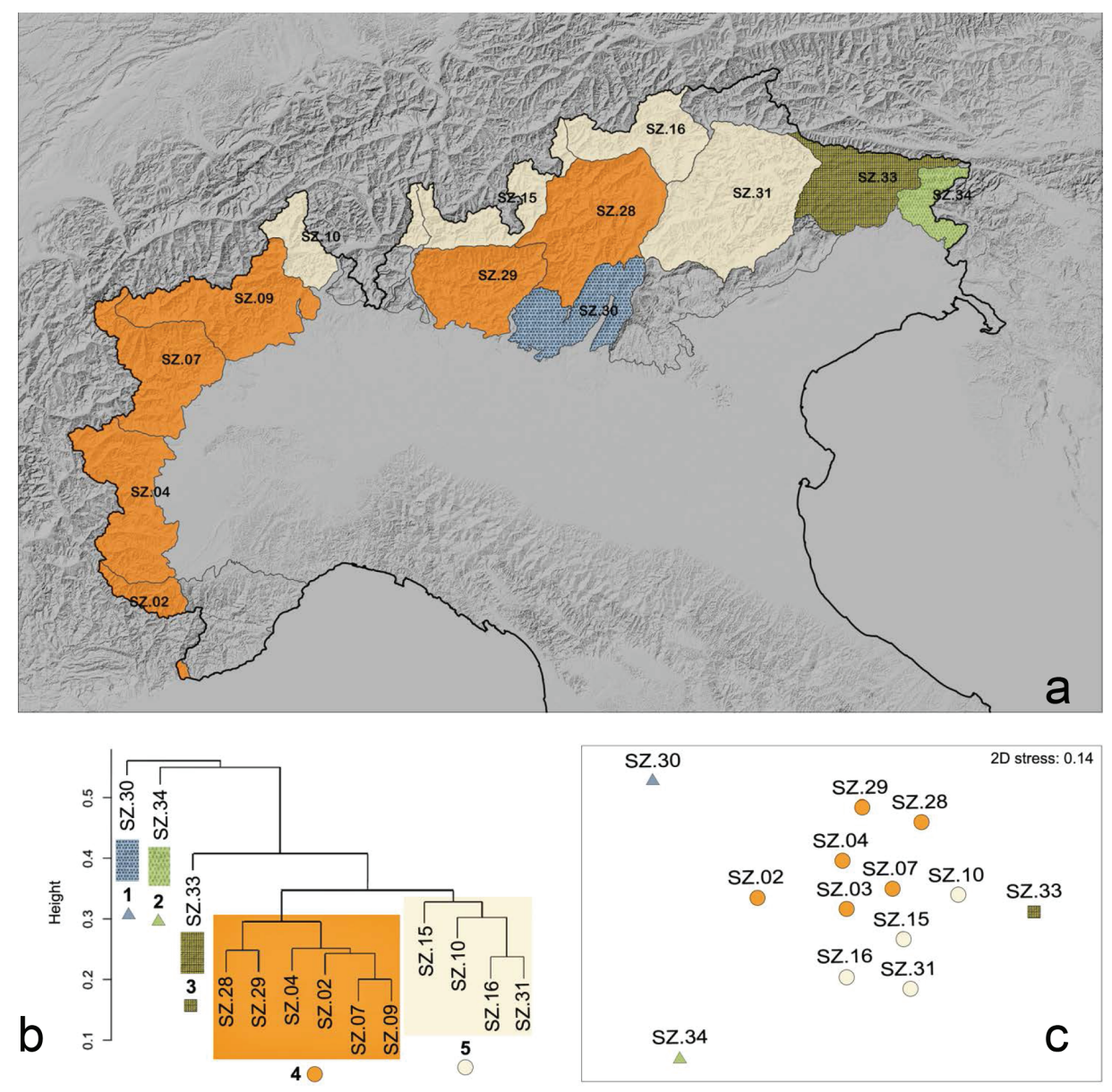

Figure 4. Results of the agglomerative hierarchical clustering analysis of SOIUSA sections based on the species turnover similarity matrix of cladoceran assemblages; codes as in Table 2. (a) Geographical distribution of the clusters in the Alpine ecoregion; (b) clustering dendrogram; (c) non-Metric Multidimensional Scaling (nMDS) ordination of the Alpine sections based on the same similarity matrix. Resultados del análisis de agrupamiento jerárquico de las secciones SOIUSA. Basado en la matriz de similitud de recambio de especies de la comunidad de cladóceros. Los códigos son iguales que en la tabla 2. (a) Distribución geográfica de los grupos en la ecorregión alpina, (b) Dendrograma de agrupamiento; (c) Ordenación (nMDS) de las secciones de los Alpes basada en la misma matriz de similitud.

tory fish, geological setting and conductivity was unimportant (the graph illustrating the relationships of variable with dbRDA axes is reported in the Supplementary information, available at http://www.limnetica.net/en/limnetica).

Although a canonical analysis based on SOIUSA sections has to be used with caution, as suggested by ANOSIM analysis, dbRDA was applied to Alpine areas as well to detect general, broad-scale trends, minimizing the influence of local scale parameters (Fig. 6a). dbRDA applied to SOIUSA sections explained $86.5 \%$ of the species distribution pattern variation along the
Alpine chain. The first two dbRDA axes explained $59 \%$ of the constrained variation and $43 \%$ of the total variation. The first axis was an altitudinal gradient, while the second axis was mainly defined by the dolomitic geological setting and the altitudinal heterogeneity. Species correlation with the first two axes was quite high (Fig. 6b). Bosmina longispina, Eurycercus lamellatus, Simocephalus vetulus, Alona guttata and Diaphanosoma brachyurum, among others, confirmed their link with low-elevation, warmer, and more productive areas. On the contrary, a group of species including Macrothrix hirsuticor- 
nis, Coronatella rectangula, Alona affinis, Acroperus angustatus and Daphnia middendorffiana showed a preference for areas with higher elevation and lower temperature and productivity, while the presence of the widespread Daphnia longispina was consistent in the more heterogeneous areas, and quite distinct from the distribution of the similar D. zschokkei, D. hyalina, and D. rosea. Finally, a group of species including Daphnia obtusa, Streblocerus serricaudatus, and Alonella excisa was found mainly in the cluster of Dolomites, Lepontine and Rhaetian Alps.

\section{DISCUSSION}

To the best of our knowledge, the present study provides the first comprehensive assessment of cladocerans in the Italian Alpine lakes, using data compiled from literature sources as well as an extensive set of newly collected samples. In total, our research indicates that at least 55 cladoceran species inhabit the lakes of the Alpine ecoregion in Italy (i.e. over $40 \%$ of the whole Italian cladoceran fauna, including 124 species: Margaritora, 1985, 2005 and unpublished checklist updates). Most species of cladocerans recorded in Alpine lakes are widely distributed across Europe as well as across continental Italy, occurring in several ecoregions (Margaritora, 2005); no one species is endemic to the Alpine ecoregion. The widespread occurrence of most species across Europe and the Alpine arc suggests that dispersal is probably not a factor limiting the occurrence of cladocerans in the studied lakes.

Only three species (Daphnia longispina, Chydorus sphaericus and Alona affinis) where widely distributed in the Alpine lakes. The amount of rare species collected in the area was quite high, with more than $80 \%$ of the species present in less than $10 \%$ of the lakes. Unfortunately, the logarithmic distribution fitted to the rank-frequency occurrence data do not offer any explanatory value for the process behind species distribution patterns. Applying a modified Yule's three-parameter model, Maruvka et al. (2011) acknowledged that many other non-biological objects, for example size of cities in a country, usage of words in human languages, or even the number of web sites with certain degree of links per year follow a hollow curve pattern. For this reason, any ecological explanation of $\log$ series distribution must be taken with caution.

The log series, introduced in ecology by Fischer et al. (1943), could have been generated by an insufficient and/or uneven sampling effort (Magurran, 2006), which prevented a complete survey of alpha-species diversity in lakes, artificially increasing the number of rare species. As
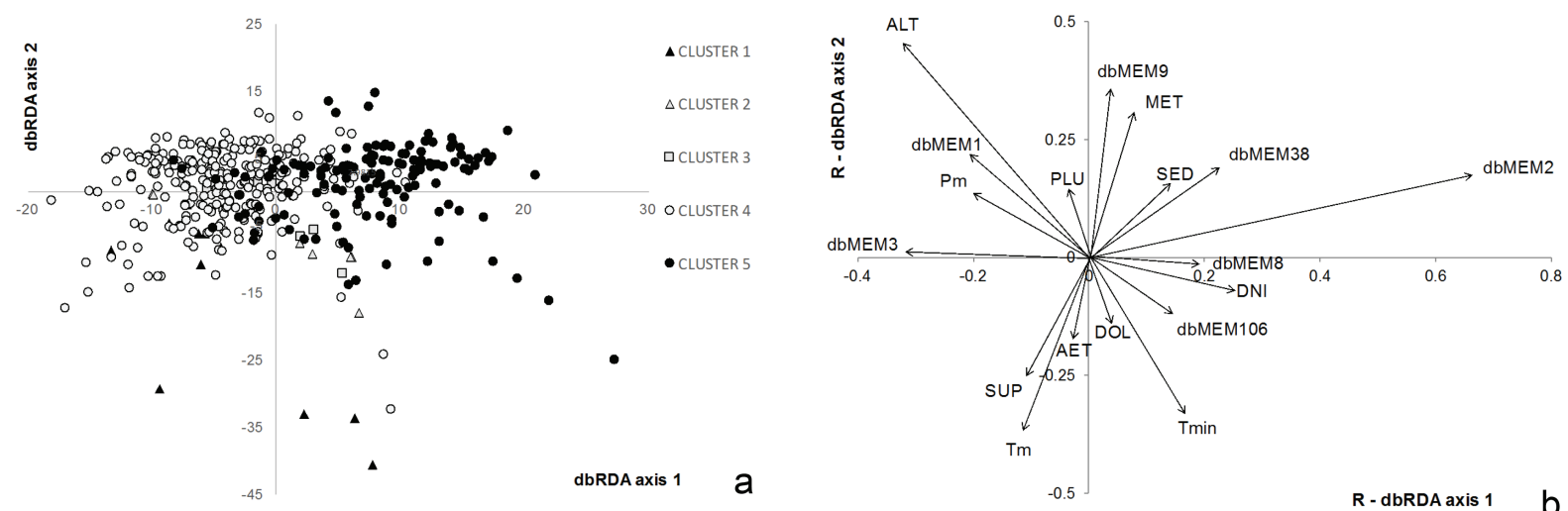

Figure 5. Results of distance-based redundancy analysis (dbRDA). (a) Plot of Alpine lakes on the plane defined by the first two canonical axes; markers correspond to the major clusters illustrated in Fig. 4. (b) Plot of the predictor variables on the plane defined by the first two canonical axes using their multiple correlation coefficients with the dbRDA axes; variable acronyms: see text. Resultados del análisis de redundancia basado en las distancias (dbRDA). (a) Plot de los lagos alpinos en el plano definido por los dos primeros ejes canónicos. Los símbolos corresponden a los grupos principales ilustrados en la Fig. 4. (b) Variables predictoras; acrónimos de las variables: ver en el texto. 

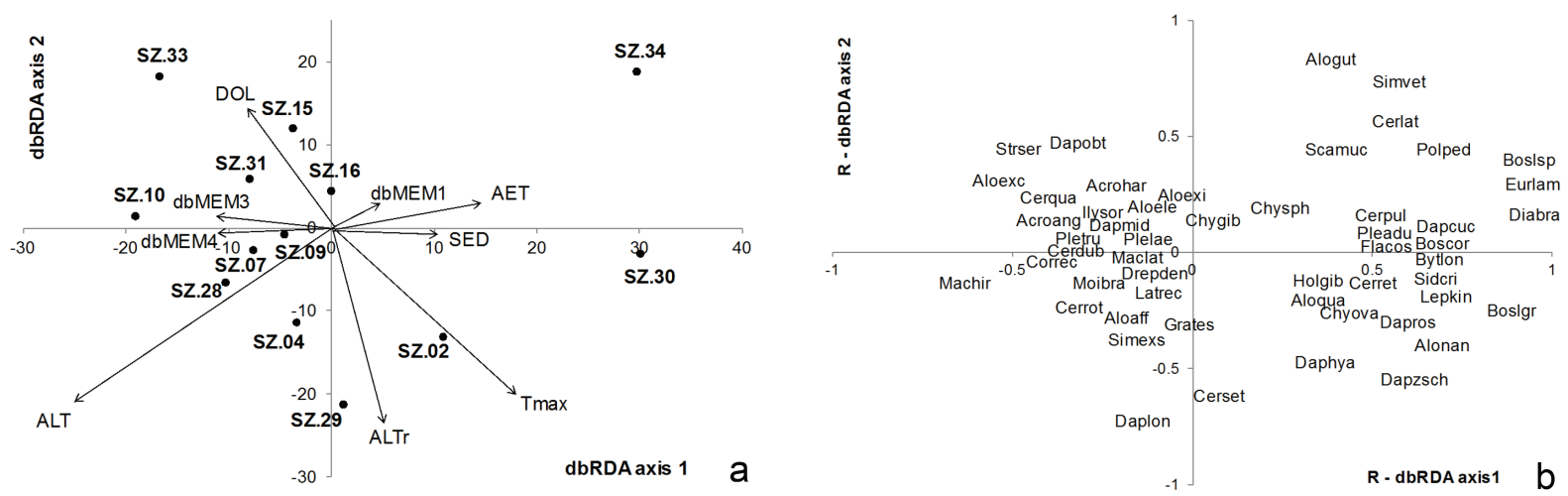

Figure 6. Results of distance-based redundancy analysis (dbRDA) applied to the SOIUSA sections. (a) Biplot of SOIUSA sections and predictor variables on the plane defined by the first two canonical axes; codes of sections as in Table 2; variable acronyms: see text. (b) Plot of cladoceran species on the plane defined by the first two canonical axes using their multiple correlation coefficients with the dbRDA axes; species acronyms as in Table 1. Resultados del análisis de redundancia basado en las distancias (dbRDA) aplicado a las secciones SOIUSA. (a) Biplot de las secciones SOIUSA y las variables predictoras en el plano definido por los dos primeros ejes canónicos; los códigos son como los de la Tabla 2; los acrónimos de las variables: ver en el texto. (b) Biplot de las especies de cladóceros; los acrónimos de las especies igual que en la Tabla 1.

with most large-scale surveys (Pinel-Alloul et al., 2013), there are caveats in our study: our sampling did not cover the whole summer growing season and the surveys published in the literature used to compile the species distribution matrix extended through more than 70 years. However, species rarefaction curves indicated a decrease in the number of uniques after 120 sampled lakes, suggesting that sampling was quite efficient. Moreover, bottom-dwelling cladocerans (see Kotov, 2006 for their definition) are well represented both in the common (Chydorus sphaericus, Alona afinis) than in rare species (Ilyocryptus sordidus, Lathonura rectirostris, Drepanothrix dentata, Pleuroxus truncates) fractions, suggesting that sampling effort covered both open water (planktonic) and bottom-dwelling (benthic) habitat in the studied lakes.

Magurran (2006) stated that a log series best fit the species-abundance data in harsh environments where few factors determine the distribution patterns. This is the case of the Alpine ecoregion, and especially of high altitude lakes. Less extreme environmental conditions give rise to other kinds of distributions, as can be observed looking at the graph reported by Pinel-Alloul et al. (2013) for a set of 1665 Canadian lakes. However, most studies refer to the whole zooplankton crustacean community, including copepods, which have very different ecological life-cycle, so that Henriques-Silva et al. (2016) suggested to disentangle the study of the two groups in macroecological and biogeographical analyses. Cladocerans cope with winter conditions by going through a diapausing phase that resists freezing and drying (Havel \& Shurin, 2004), providing long-term persistence in harsh environments. Moreover, cladocerans are mostly cyclic parthenogenetic organisms that produce diapausing eggs during the sexual phase; for this reason, they need at least two generations to produce resting eggs. Cladocerans dwelling in high-altitude lakes on the Alps experience cold temperatures; they have a shorter growing season and a slower metabolism than at lower altitudes. High-altitude conditions might thus exclude several species which are unable to complete their life cycle (Henriques-Silva et al., 2016), explaining the decrease of species richness with altitude and decreasing temperature, observed in our analysis, and the high degree of rarity.

A further explanation of the excess of rare species may be found in cladoceran dispersal ways and colonization patterns (Henriques-Silva et al., 2016). A post-glacial colonization of lakes may have given rise to a log series distribution: in 
analogy to species-abundance models (Magurran, 2006), if species arrived in an unsaturated area (like the Alpine chain after the Last Glacial Maximum) at irregular intervals of time, occupying the free fractions of remaining lakes, a log series distribution can be predicted. The monopolization hypothesis, proposed by De Meester et al. (2002), and lately extended to multiple species communities (De Meester et al., 2016), may support our explanation. Following Henriques-Silva et al. (2016), we suppose that Alpine lakes were first randomly colonized after glaciers retreat by long-distance dispersal events (for example resting eggs carried by birds or winds: Incagnone et al., 2014). Rapid population growth rates due to asexual reproduction enabled early colonizers to adapt quickly to the local environment (De Meester et al., 2002), enhancing priority effects and precluding the establishment of later migrants through niche pre-emption (De Meester et al., 2016). The monopolization hypothesis predicts the occupation only of free niches in remaining lakes by more recent colonizers, which originates the log series distribution of species frequencies.

Apart from statistical distributions, and despite the widespread occurrence of most species found in Alpine lakes, there were distinct differences in the relative frequency of cladocerans across Alpine regions, as described by cluster analysis and dbRDA, suggesting that factors other than dispersal may influence cladoceran distribution in Alpine lakes. We found that both spatial variables (which are mainly linked to dispersal) and climatic variables (mainly linked to the altitudinal gradient) explained the variation in cladoceran assemblage structure along the Alpine arc. Despite the highly significant correlation between spatial and environmental predictor variables and the species distribution similarity matrix, the total amount of variation explained considering lakes as sampling units in multivariate analysis was quite low, but comparable to other zooplankton surveys that used ordination techniques (Pinel-Alloul et al., 2013; Sweetman et al., 2010; Anas et al., 2014). Leibold et al. (2010) demonstrated that cladocerans respond more to local-scale environmental factors in lakes than to regional-scale factors. Moreover, Anas et al. (2014) found that assemblage structure of crustacean zooplankton in northwest Saskatchewan lakes (Canada) were largely regulated by local environmental factors, even if the total variance explained, accounting also for local factors (including water chemistry and fish predation), did not exceed $24 \%$. We added some local explanatory variables (depth, water conductivity, presence/absence of predatory fish, and natu$\mathrm{ral} /$ artificial origin of the basins) using a subset of 199 lakes, increasing the explained variance approximately from 15 to $20 \%$, in agreement with Anas et al. (2014) results. The unexplained variation seems unavoidable and can be simply attributed to noisiness of species data and unmeasured local biotic factors; for this reason, its influence on the main results of our macroecological analysis seems negligible.

Clustering lakes within geographical macro-areas (like the SOIUSA sections used in our study), as usual in large-scale analyses (Pinel-Alloul et al., 2013; Henriques-Silva et al., 2016; Marrone et al., 2017) allowed us to focus on broad-scale macroecological patterns, avoiding the effect of local scale variables. dbRDA applied to SOIUSA sections explained most (86.5 $\%)$ of the total variation of species distribution pattern. Ecological factors linked to the altitudinal gradient like actual evapotranspiration (i.e. a surrogate of productivity in freshwaters, see Eme et al., 2015 and Stoch et al., 2016), temperature and precipitation, together with the geological setting (influencing water chemistry) and altitudinal heterogeneity were the major ecological determinants of the large-scale cladoceran distribution in the SOIUSA sections across the Alpine chain. The role of solar radiation alone as a major determinant of regional species richness (Pinel-Alloul et al., 2013) was not supported by our multivariate analysis conducted at the scale of the Alpine ecoregion. These results support the prediction of Henriques-Silva et al. (2016) regarding environmental filtering and a strong relationship to climatic factors for cladocerans. However, beta-diversity partitioning analysis performed by Henriques-Silva et al. (2016) showed that $83 \%$ of the variation in cladoceran beta diversity $\left(\beta_{\text {sor }}\right)$ was due to pure spatial turnover and $17 \%$ to nestedness, suggesting that 
cladoceran beta diversity in Canadian lakes was partially driven by species loss. Our study did not support this hypothesis, being nestedness negligible in Alpine cladoceran assemblages. The habitat heterogeneity of the Alpine chain, rich of barriers compared to the Canadian area studied by Henriques-Silva et al. (2016), as well as the difference of scale (our study concentrated on a single ecoregion) may be plausible explanations of this discrepancy, suggesting that species turnover alone explains the variation in species composition of lake assemblages along the Alpine chain. This result prevents a generalization of the hypothesis of the role of nestedness in shaping beta-diversity patterns in zooplankton along multiple spatial scales.

\section{CONCLUSION}

Our broad-scale survey of cladocerans in Alpine lakes gave additional support to the hypothesis put forward by Pinel-Alloul (1995), Pinel-Alloul et al. (2013) and Shurin et al. (2007) which stated that abiotic environmental gradients will be the most important drivers of spatial variation in zooplanktonic community structure at large scale. However, given the high dispersal ability of cladoceran species, their peculiar life strategy including the production of diapausing eggs, and their compliance to the monopolization hypothesis (De Meester et al., 2002), allowed us to formulate a novel hypothesis on the origin and variation of cladoceran assemblages along the Alpine arc accounting for dispersal ability, life-cycle characteristics and environmental filtering. Our data suggest that this is a likely explanation of the excess of rarity in these environments, and of the observed log series distribution of species frequencies in the area. Moreover, the strong relationship between local cladoceran species richness and the altitudinal gradient (including all the ecological parameters that covary with altitude), evidenced by our analysis, reinforces the role of the peculiar cladoceran life cycle based on cyclic parthenogenesis in shaping species distribution and species richness patterns.

Although our results partly agree with the statements by Leibold et al. (2010), Anas et al. (2014), and Henriques-Silva et al. (2016) that cladocerans respond also to local-scale environmental factors in lakes, a macroecological approach revealed a large-scale distribution pattern which can be disentangled from local variables effects. Hypotheses related to the the importance of nestedness in shaping beta-diversity patterns (Henriques-Silva $e t$ $a l ., 2016$ ) as well as the role of solar radiation as a major determinant of regional species richness (Pinel-Alloul et al., 2013) were not confirmed at the scale of our extensive survey on Alpine lakes, emphasizing the presence of scale-dependent spatial and environmental determinants of cladoceran distribution patterns.

\section{ACKNOWLEDGEMENTS}

The authors thank two anonymous reviewers; with their constructive observations they have greatly improved the manuscripts. Many thanks are due to Jaime Ordóñez Salinas for the Spanish translation of abstract and captions and to Paul Tout for the revision of the text and the improvements made to English style.

\section{REFERENCES}

ADAMOWICZ, S.J., \& A. PURVIS, 2005. How many branchiopod crustacean species are there? Quantifying the components of underestimation. Global Ecology \& Biogeography, 14, 455-468.

ANAS, M.U.M., K.A. SCOTT, R.N. COOPER \& B. WISSELA, 2014. Zooplankton communities are good indicators of potential impacts of Athabasca oil sands operations on downwind boreal lakes. Canadian Journal of Fisheries and Aquatic Sciences, 71, 5, 719-732. DOI: 10.1139/cjfas-2013-0472

BASELGA, A., 2010. Partitioning the turnover and nestedness components of beta diversity. Global Ecology \& Biogeography, 19, 134-143.

BASELGA, A., \& C.D.L. ORME, 2012. betapart: an R package for the study of beta diversity. Methods in Ecology and Evolution, 3, 808-812.

BLASI, C., G. CAPOTORTI, R. COPIZ, D. GUIDA, B. MOLLO, D. SMIRAGLIA, \& L. ZAVATTERO, 2014. Classification and mapping of the ecoregions of Italy. Plant Biosys- 
tems - An International Journal Dealing with all Aspects of Plant Biology, 148, 6, 1255-1345, DOI: 10.1080/11263504.2014. 985756

BŁĘDZKI, L. A., \& J. I. RYBAK, 2016. Freshwater Crustacean Zooplankton of Europe. Cladocera \& Copepoda (Calanoida, Cyclopoida) key to species identification. Springer, Switzerland, 1-918.

BORCARD, D., \& P. LEGENDRE, 2002. All-scale spatial analysis of ecological data by means of principal coordinates of neighbour matrices. Ecological Modelling, 153, 51-68.

CLARKE, K. R., 1993. Non-parametric multivariate analyses of changes in community structure. Australian Journal of Ecology, 18, 117-143.

COURCHAMP, F., T. CLUTTON-BROCK, \& B. GRENFELL, 1999. Inverse density dependence and the Allee effect. Trends in Ecology and Evolution, 14, 405-410.

DAHL, E., 1987. The nunatak theory reconsidered. Ecological Bulletins, 38, 77-94.

DE MEESTER, L., A. GÓMEZ, B. OKAMURA, \& K. SCHWENK, 2002. The monopolization hypothesis and the dispersal-gene flow paradox in aquatic organisms. Acta Oecologica, 23, 121-135.

DE MEESTER, L., J. VANOVERBEKE, L.J. KILSDONK, \& M.C. URBAN, 2016. Evolving perspectives on monopolization and priority effects. Trends in Ecology and Evolution, 31, 136-146.

DRAY, S. 2008. spacemakeR: spatial modelling. $\mathrm{R}$ package ver. 00-5. https://r-forge.r-project. org/R/?group_id=195. Accessed 30 Jan 2018.

DRAY, S., 2009. packfor: forward Selection with Permutation (Canoco p. 46). R package version 0.0-8. https://r-forge.r-project.org/R/ ?group_id=195. Accessed 30 Jan 2018.

DRAY, S., R. PÉLISSIER, P. COUTERON, M. J. FORTIN, P. LEGENDRE, P. R. PERES-NETO, E. BELLIER, R. BIVAND, F. G. BLANCHET, M. DE CÁCERES, A. B. DUFOUR, E. HEEGAARD, T. JOMBART, F. MUNOZ, J. OKSANEN, J. THIOULOUSE, \& H. H. WAGNER, 2012. Community ecology in the age of multivariate multiscale spatial analysis. Ecological
Monographs, 82, 257-275.

EME, D., M. ZAGMAJSTER, C. FIŠER, D. GALASSI, P. MARMONIER, F. STOCH, J.F. CORNU, T. OBERDORFF \& F. MALARD, 2015. Multi-causality and spatial non-stationarity in the determinants of groundwater crustacean diversity in Europe. Ecography, 38, 531-540.

FISHER, R.A., A.S. CORBET, \& C.B. WILLIAMS, 1943. The relation between the number of species and the number of individuals in a random sample of an animal population. The Journal of Animal Ecology, 12, 1, 42-58.

FURRER, R., D. NYCHKA, \& S. SAIN, 2011. Fields: tools for spatial data. $\mathrm{R}$ package version 6.6. http://CRAN.R-project.org/ package $=$ fields. Accessed 30 Jan 2018.

GUILIZZONI P., A. LAMI, M. MANCA, S. MUSAZZI, \& A. MARCHETTO, 2006. Palaeoenvironmental changes inferred from biological remains in short lake sediment cores from the Central Alps and Dolomites. Hydrobiologia, 562, 167-191. DOI: 10.1007/ s10750-005-1810-0

GIUSSANI, G., R. DE BERNARDI, R. MOSELLO, I. ORIGGI \& T. RUFFONI, 1986. Indagine limnologica sui laghi alpini d'alta quota. Documenta dell'Istituto Italiano di Idrobiologia, 9: 1-415.

HAILESELASIE T.H., J. MERGEAY, L.J. WEIDER, R. SOMMARUGA, T.A. DAVIDSON, M. MEERHOFF, H. ARNDT, J. KLAUS, E. JEPPESEN, \& L. DE MEESTER, 2016. Environment not dispersal limitation drives clonal composition of Arctic Daphnia in a recently deglaciated area. Molecular Ecology, 25, 23, 5830-5842. DOI: 10.1111/mec. 13843

HAWKINS, B.A., R. FIELD, H.V. CORNELL, D.J. CURRIE, J.F. GUÉGAN, D.M. KAUFMAN, J.T. KERR, G.G. MITTELBACH, T. OBERDORFF, E.M. O'BRIEN, E.E. PORTER, \& J.R.G. TURNER, 2003. Energy, water and broad-scale geographic patterns of species richness. Ecology, 84, 3105-3117.

HAVEL, J.E., \& J.B. SHURIN, 2004. Mechanisms, effects, and scales of dispersal in freshwater zooplankton. Limnology and Oceanography, 49, 1229-1238. 
HENRIQUES-SILVA, R., B. PINEL-ALLOUL, \& P.R. PERES-NETO, 2016. Climate, history and life-history strategies interact in explaining differential macroecological patterns in freshwater zooplankton. Global Ecology and Biogeography, 25, 1454-1465. DOI: 10.1111/geb.12505

HIJMANS, R. J., S. E. CAMERON, J. L. PARRA, P. G. JONES, \& A. JARVIS, 2005. Very high resolution interpolated climate surfaces for global land areas. International Journal of Climatology, 25, 1965-1978.

INCAGNONE, G., F. MARRONE, R. BARONE, L. ROBBA \& L. NASELLI-FLORES, 2015. How do freshwater organisms cross the "dry ocean"? A review on passive dispersal and colonization processes with a special focus on temporary ponds. Hydrobiologia, 750: 103-123.

KOTOV, A.A., 2006. Adaptations of Anomopoda crustaceans (Cladocera) to the benthic mode of life. Entomological Review, 86, Suppl. 2, 210-225.

LEIBOLD, M.A., E.P. ECONOMO, \& P. PERES-NETO, 2010. Metacommunity phylogenetics: separating the roles of environmental filters and historical biogeography. Ecology Letters, 13, 1290-1299.

LEGENDRE, P., \& M. J. ANDERSON, 1999. Distance-based redundancy analysis: testing multispecies responses in multifactorial ecological experiments. Ecological Monographs, 69, 1-24.

LEGENDRE, P., \& L. LEGENDRE, 2012. Numerical Ecology, 3rd ed. Elsevier, Oxford.

MAGURRAN, A., 2006. Measuring Biological Diversity. 2nd ed. Blackwell Publishing, 1-256.

MARGARITORA, F.G., 1985. Cladocera. Fauna d'Italia, Calderini, Bologna, 23, 1-399.

MARGARITORA, F.G., 2005. Crustacea, Branchiopoda, Cladocera. In: Ruffo, S., \& F. Stoch (eds.), Checklist e distribuzione della fauna italiana.10.000 specie terrestri e delle acque interne. Memorie del Museo Civico di Storia Naturale di Verona, 2. Serie, Sezione Scienze della Vita, 16, 87-89.

MARQUET, P.A., M. FERNÁNDEZ, S.A. NAVARRETE, \& C. VALDOVINOS, 2004.
Diversity emerging: towards a deconstruction of biodiversity patterns. In: Lomolino, M.V., \& L.R. Heaney (eds.), Frontiers of Biogeography. Sinuaer Associates, Sunderland, MA.

MARRONE, F., G. ALFONSO, L. NASELLI-FLORES, \& F. STOCH, 2017. Diversity patterns and biogeography of Diaptomidae (Copepoda, Calanoida) in the Western Palearctic. Hydrobiologia, 800, 45-60. DOI: 10.1007/s10750-017-3216-1

MARUVKA, Y.E., D.A. KESSLER \& N.M. SHNERB, 2011. The birth-death-mutation process: a new paradigm for fat tailed distributions. PloS ONE, 6, 11, e26480. DOI: 10.1371/journal.pone.0026480.

O'BRIEN, E. M., 2006. Biological relativity to water-energy dynamics. Journal of Biogeography, 33, 1868-1888.

OKSANEN J., F. G. BLANCHET, M. FRIENDLY, R. KINDT, P. LEGENDRE, D. MCGLINN, P. R. MINCHIN, R. B. O'HARA, G. L. SIMPSON, P. SOLYMOS, M. H. H. STEVENS, E. SZOECS, \& H. WAGNER, 2017. 'vegan'. Community Ecology Package. R Package Version 2.4-2. http://CRAN.R-project. org/package=vegan. Accessed 23 Jan 2018.

PESTA, O., 1929. Der Hochgebirgssee der Alpen. Die Binnengewässer, Stuttgart, E. Schweizerbart'sche Verlagsbuchhandlung, $1-156$.

PINEL-ALLOUL, B., 1995. Spatial heterogeneity as a multiscale characteristic of zooplankton community. Hydrobiologia, 300/301, 17-42.

PINEL-ALLOUL, B., A. ANDRÉ, P. LEGENDRE, J.A. CARDILLE, K. PATALAS, \& A. SALKI, 2013. Large-scale geographic patterns of diversity and community structure of pelagic crustacean zooplankton in Canadian lakes. Global Ecology and Biogeography, 22: 784-795. DOI: 10.1111/geb.12041

PETRUSEK A., A. HOBÆK, J. PETTER NILSSEN, M. SKAGE, M. CERNY, N. BREDE, \& K. SCHWENK, 2008. A taxonomic reappraisal of the European Daphnia longispina complex (Crustacea, Cladocera, Anomopoda). Zoologica Scripta, 37, 507-519. DOI: 10.1111/j.1463-6409.2008.00336.x

QGIS DEVELOPMENT TEAM, 2016. QGIS 
geographic information system. Open source geospatial foundation. http://qgis.osgeo.org. Accessed 23 Jan 2018.

R DEVELOPMENT CORE TEAM, 2016. A language and environment for statistical computing. R Foundation for Statistical Computing, Vienna. http://www.R-project.org. Accessed 30 Jan 2018.

SHURIN, J.B., S.E. ARNOTT, H. HILLEBRAND, A. LONGMUIR, B. PINEL-ALLOUL, M. WINDER, \& M.D. YAN, 2007. Diversity-stability relationships varies with latitude in zooplankton. Ecology Letters, 10, $1-8$.

STOCH, F., M. KORN, S. TURKI, L. NASELLI-FLORES, \& F. MARRONE, 2016. The role of spatial environmental factors as determinants of large branchiopod distribution in Tunisian temporary ponds. Hydrobiologia, 782, 37-51.

SWEETMAN, J.N., K.M. RÜHLAND, \& J.P. SMOL, 2010. Environmental and spatial factors influencing the distribution of cladocerans in lakes across the central Canadian Arctic treeline region. Journal of Limnology, 69, 1, 76-87. DOI: 10.3274/JL10-69-1-07

TONOLLI, V., \& L. TONOLLI, 1951. Osservazioni sulla biologia ed ecologia di 170 popolamenti zooplanctonici di laghi italiani di alta quota. Memorie dell'Istituto italiano di Idrobiologia, Pallanza, 6: 53-136

TRABUCCO, A., \& R. J. ZOMER, 2010. Global soil water balance geospatial database. CGIAR consortium for spatial information. http://www.cgiar-csi.org/data/global-highresolutionsoil-water-balance. Accessed 30 Jan 2018.

VAN DAMME, K., A.A. KOTOV, \& H.J. DUMONT, 2010. A checklist of names in Alona Baird 1843 (Crustacea: Cladocera: Chydoridae) and their current status: an analysis of the taxonomy of a lump genus. Zootaxa, 2333, 1-63.

WINDER, M., M.T. MONAGHAN, \& P. SPAAK, 2001. Have human impacts changed Alpine zooplankton diversity over the Past 100 Years? Arctic, Antarctic and Alpine Research, 33, 4, 467-475.

ZSCHOKKE, E, 1900. Die Tierwelt der Hochgebirgsseen. Neue Denkschriften der schweizerischen naturforschenden Gesellschaft, $1-400$.

ZSCHOKKE, E, 1908. Die Resultate der zoologischen Eforschung hochalpiner Wasserbecken seit dem Jahre 1900. Internationale Revue der gesamten Hydrobiologie und Hydrographie, Leipzig, Werner Klinkhardt Verlag, 1-235.

Con el apoyo de:

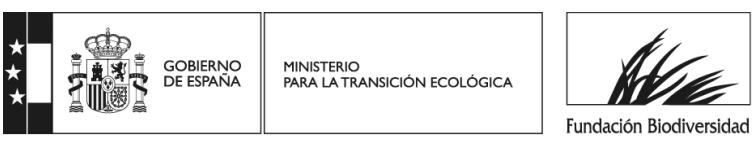

